\title{
Albian - Cenomanian resedimented limestone in the Lower flyschoid Formation of the Mt. Mrzli Vrh Area (Tolmin region, NW Slovenia)
}

\section{Albijsko cenomanijski presedimentirani apnenci spodnje flišoidne formacije z območja Mrzlega vrha severno od Tolmina (SZ Slovenija)}

\author{
Boštjan ROŽIČ
}

Oddelek za geologijo, Naravoslovnotehniška fakulteta, Aškerčeva 12, 1000 Ljubljana, Slovenija

Key words: Middle Cretaceous, resedimented carbonates, Lower flyschoid formation, Slovenian basin, Tolmin Nappe, Slovenia

Ključne besede: srednja kreda, presedimentirani karbonati, spodnja flišoidna formacija, Slovenski bazen, Tolminski pokrov, Slovenija

\begin{abstract}
The Lower flyschoid formation of the Slovenian Basin is characterized by marl, shale and subordinate chert, interbedded with micritic limestone and resedimented carbonates. In the upper part of the formation marly and micritic limestones commonly prevail. The maximum range of the formation is Albian to Turonian. Contact with underlying successions is always erosional and the formation usually overlies upper Tithonian to Neocomian Biancone limestone. In the Mt. Mrzli vrh area, the formation is composed of upper Albian to lower Cenomanian resedimented limestone and upper Cenomanian to Turonian shale and marl, marly limestone and cherts. It directly overlies Lower Jurassic basinal succession or Upper Triassic platform dolomite. In this study resedimented carbonates of the formation were analyzed. A two $\mathrm{km}^{2}$ area was mapped and an $80 \mathrm{~m}$ thick Mt. Grmuč section was studied in detail. This section consists of micritic limestone and abundant breccia and calcarenite. Whereas the calcarenite is predominantly composed of platform-derived material, the breccia consists of slope-to-basin intraclasts and various extraclasts of older platform and basin deposits. The analyzed facies association indicates a lower slope depositional environment. A correlation with other successions of the Lower flyschoid formation reveals that resedimented carbonates are the thickest and most abundant in the Tolmin region, that paleogeographically corresponds to the western part of the Slovenian Basin. Intense Albian - Cenomanian tectonic activity is inferable regionally, from platform as well as basinal successions, and is thought to have been the major factor causing and controlling the carbonate gravity-flows sedimentation in the Slovenian Basin. The Mt. Mrzli vrh area is important for paleotopographic reconstruction because it links the central Slovenian Basin with the margin of the Dinaric Carbonate Platform. The observed lateral facies distribution, the composition of lithoclasts and variable degree of erosion between the Lower flyschoid formation and underlying beds indicate a steep, faultbounded slope, along which older platform and basinal succession were eroded.
\end{abstract}

\section{Kratka vsebina}

Spodnjo flišoidno formacijo Slovenskega bazena sestavljajo laporovci, glinavci in podrejeno roženci, ki se menjavajo s plastmi mikritnih apnencev in presedimentiranih karbonatov. V zgornjem delu formacije prevladujejo lapornati in mikritni apnenci. Spodnja meja je vedno erozijska in formacija, ki je albijsko-turonijske starosti, običajno leži na zgornjetithonijskem do neocomijskem Biancone apnencu. Na območju Mrzlega vrha formacijo sestavljajo zgornjealbijski do spodnjecenomanijski presedimentirani apnenci in zgornjecenomanijski do turonijski glinavci, laporovci in lapornati apnenci ter roženci. $\mathrm{Na}$ 
tem območju je formacija odložena na spodnjejurske ali neposredno na triasne kamnine. $\mathrm{V}$ sklopu raziskave je bila izdelana geološka karta območja Mrzlega vrha in detajlno proučen $80 \mathrm{~m}$ dolg profil Grmuč v spodnjem delu formacije. V profilu se paketi mikritnega apnenca menjavajo s pogostimi plastmi breče in kalkarenita. Kalkarenit je sestavljen predvsem iz platformnega materiala, medtem ko so breče iz intraklastov bazenskih kamnin in kamnin pobočja ter močno raznolikih ekstraklastov starejših platformnih in bazenskih kamnin. Raziskana faciesna združba je značilna za sedimentacijo v spodnjem delu pobočja. Primerjava z drugimi profili spodnje flišoidne formacije je pokazala, da so presedimentirani karbonati najdebelejši in najbolj pogosti predvsem v okolici Tolmina, torej na zahodnem delu Slovenskega bazena. Močna albijsko - cenomanijska tektonska aktivnost, ki je regionalno prepoznavna tako v platformnih kot tudi bazenskih razvojih, je bila najverjetneje glavni vzrok za nastanek gravitacijskih tokov v Slovenskem bazenu. Območje Mrzlega vrha je pomembno za rekonstrukcijo paleotopografije, saj predstavlja povezavo med Dinarsko karbonatno platformo in centralnim delom Slovenskega bazena. Lateralna razporeditev faciesnih združb, sestava litoklastov v presedimentiranih apnencih in različna stopnja erozije med spodnjo flišoidno formacijo in spodaj ležečimi plastmi kažejo na zelo strmo, s prelomi presekano pobočje. Na tako izoblikovanem pobočju je prihajalo do erozije starejših platformnih in bazenskih sedimentov.

\section{Introduction}

The Mt. Grmuč section is located in the Mt. Mrzli vrh area in the foothills of the Julian Alps north of Tolmin in north-western Slovenia (Fig 1.). The Mt. Mrzli vrh area is characterized by Upper Triassic shallowwater massive dolomite overlain by the $\mathrm{Ju}-$ rassic to Cretaceous succession of the

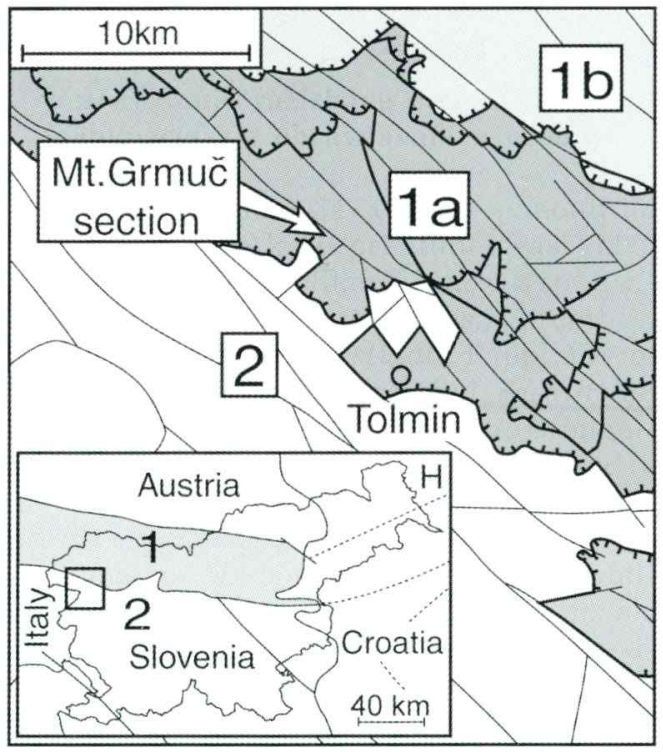

Fig. 1. Location and structural map of the area (modified after Buser, 1986 \& Placer, 1999):

1 Southern Alps; 1a Tolmin Nappe, 1b Julian Nappe, 2 Dinarides
Slovenian Basin. This paleogeographic unit formed at the end of the Triassic and beginning of the Jurassic and was placed between the Julian Carbonate Platform to the north and the Dinaric Carbonate Platform to the south. In the Early Jurassic the Julian Carbonate Platform subsided, while the Dinaric Carbonate Platform remained shallow throughout the entire Mesozoic (Buser, 1989).

Up until recently, basic stratigraphic work was focused on the central part of the Slovenian Basin (Kossmat, 1907; Winkler, 1921; Caron \& Cousin, 1972, Cousin, 1981, Buser, 1987). The Mt. Grmuč section characterized by micritic limestone interbedded with abundant carbonate gravity-flow deposits represents the proximal succession of the Lower flyschoid formation (defined by Caron \& Cousin, 1972). The maximum time span of the formation is Aptian to Turonian, although the lower boundary has not been satisfactorily dated and Aptian is regarded as questionable (Caron \& Cousin, 1972). In the central part of the basin this formation is characterized by marl and shale interbedded with carbonate gravity-flow deposits, mostly graded calcarenites. In the upper part of the formation (upper Cenomanian - Turonian) thin-bedded reddish marly and micritic limestone becomes abundant and commonly prevails. In the basic geological map of $\mathrm{Yu}-$ goslavia (1:100 000, sheet Tolmin) these two 
parts of the formation are mapped as different lithostratigraphic units (B user, 1986). Generally, the Lower flyschoid formation as defined by Caron and Cousin (1972) lies with erosional contact over the upper Tithonian to Neocomian Biancone limestone and is overlain by the Volče Limestone Formation. In the Mt. Mrzli vrh area the base of the formation is younger and the stratigraphic gap below the formation is greater.

An important stratigraphic research of the proximal succession of the Lower flyschoid formation, which includes the Mt. Mrzli vrh area, was undertaken by S a miee (1999). He investigated three sections and correlated the Kanalski vrh section, placed on the Dinaric Carbonate Platform margin, with the Mt. Mrzli vrh and Tolminske Ravne basinal sections characterized by abundant resedimented carbonates. The Mt. Mrzli vrh section of Sammie is located close to the Mt. Grmuč section and assigned to upper Albian to lower Cenomanian. Samiee also discussed sedimentary processes and concluded that carbonate gravity-flow deposits are abundant in the Mt. Mrzli vrh area but decline towards the Tolminske Ravne area, i.e. more distal parts of the basin.

Facies analysis of the Mt. Grmuč section and mapping of the Mt. Mrzli vrh area bring new data that contribute significantly to our understanding of the middle Cretaceous sedimentary and tectonic development of the Slovenian Basin. These data are also important for reconstruction of the paleotopography. No continuous transition is preserved between the Dinaric Carbonate Platform and the Slovenian Basin but the investigated succession of the Mrzli vrh area represents the most proximal part of the Lower flyschoid formation with respect to the Dinaric Carbonate Platform.

The aims of this study are to:

1) describe facies associations and determine the composition of resedimented carbonates and micritic limestone in the Mt. Grmuč section,

2) interpret the sedimentary environment of the Lower flyschoid formation in the Mt. Mrzli vrh area, and

3 ) correlate the studied succession with contemporaneous successions of the Dinaric Carbonate Platform and the central part of the Slovenian Basin and to reconstruct the paleotopography between the platform and the basin.

\section{Geological setting and general description of the mapped area}

The studied area is part of a complex geological structure formed during the Alpine orogeny. Sedimentary successions of the Slovenian Basin structurally belong to the Tolmin Nappe which, together with overlying Julian Nappe (Julian Carbonate Platform), forms the easternmost continuation of the Southern Alps (Fig. 1) (Pla c e r, 1999). Within the Tolmin Nappe three nappes were further recognized by Buser (1986). Mt. Mrzli vrh is situated in the southernmost, structurally lowest Podmelec Nappe, where basinal successions most proximal to the Dinaric Carbonate Platform are exposed. The structure of the region is complex since the Eocene or earlier, SW-directed ("Dinaric") nappe emplacement is overprinted by the younger, Oligocene, S-directed ("Southalpine") thrusting (Dognioli \& Bosellini, 1987, Dognioli \& Siorpeas, 1990, Placer \& Car, 1998, Placer, 1999). It is further complicated due to the neotectonic strike-slip faulting of which the NW-SE extending Idrija fault is dominant in the area (B us er , 1986). For this reason, a detailed geological map of the Mt. Mrzli vrh area is included in this study (Fig 2.). Mapping revealed that the area is fragmented by a strong W-E fault into blocks with characteristically different basinal successions.

In the Mt. Mrzli vrh area an Upper Triassic to Upper Cretaceous succession is exposed (Fig. 2, 3A). The Upper Triassic is represented by Carnian thin-bedded limestone with chert nodules, overlain by Norian-Rhaetian massive dolomite that laterally passes into bedded Bača dolomite (Buser, 1987). Bedded dolomite is partly replaced by chert nodules in which "ghosts" of spherical grains, probably ooids were found. In the northern block the Lower Jurassic succession is preserved. It begins with basal breccias overlain by bedded siliceous limestone (Rožič, 2005). Leonidakis et al. (2003) assumed that the upper part of the succession, where siliceous limestone is interbedded with marls, is of Middle Jurassic age. This succession is overlain by a $130 \mathrm{~m}$ 
thick upper Albian to lower Cenomanian Lower flyschoid formation characterized by micritic limestone, breccia and calcarenite.
In the southern block the gap is stronger; the formation is thicker (approximately $220 \mathrm{~m}$ ) and starts with partly dolomitized basal

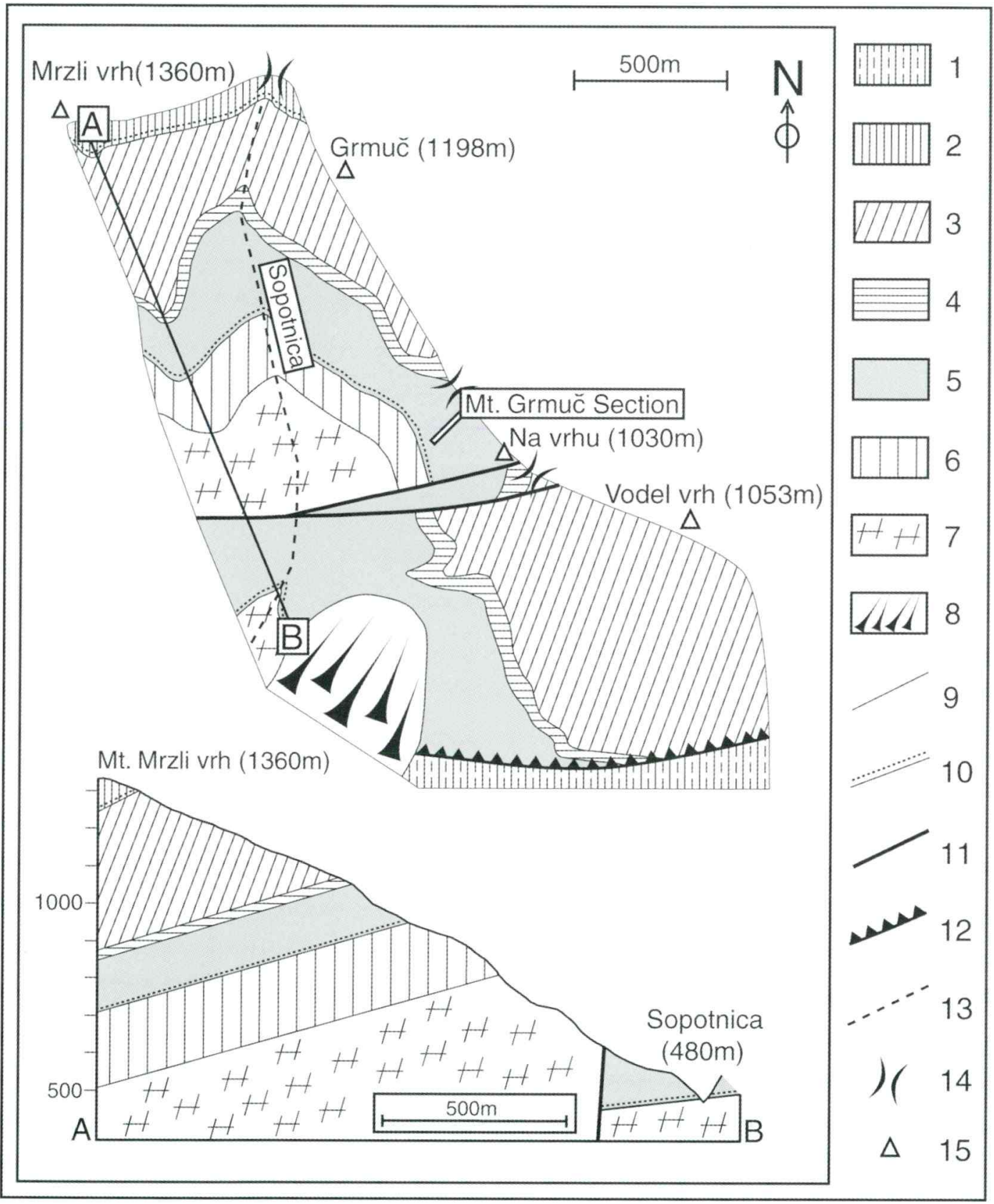

Fig. 2. Geological map and cross-section of the Mt. Mrzli vrh area: 1 Upper flyschoid formation, 2 Basal breccia of the Upper flyschoid formation, 3 Volče Limestone, 4 red to green marl, shale, chert, marly limestone and calcarenite, 5 Lower flyschoid formation, 6 Jurassic basinal succession, 7 Triassic basement, 8 Quaternary, 9 normal boundary, 10 erosional boundary, 11 fault-boundary between $\mathrm{N}$ and $\mathrm{S}$ blocks, 12 overthrust, 13 stream, 14 mountain saddle, 15 mountain peak. 
breccia lying directly on Upper Triassic massive dolomite. The Mt. Grmuč section (Fig. 3B, C) is placed in the northern block in the upper part of the formation approximately $10 \mathrm{~m}$ below the contact with marl and shale (Figs. 2, 3). The base of the section is of late Albian age, as suggested by the keeled globotruncanids in finer beds. The first occurrence of these foraminifers is placed in the late middle Albian (Caron, 1985). The section records almost the entire upper part of the succession represented by abundant resedimented carbonates that was assigned to lower Cenomanian by Samiee (1999).

The Lower flyschoid formation ends with $20 \mathrm{~m}$ of dark green to red shale, marl and marly limestone interbedded with red and yellow to green chert. The darker, greenish parts are impregnated with manganese. Beds of dark grey graded calcarenite are present in the southern block.

A thick succession (approximately $300 \mathrm{~m}$ ) of light grey bedded pelagic limestone and resedimented carbonates, mostly calcarenite with chert nodules follows. Beds of carbonate breccias are rare in the northern block, while in the southern block they become abundant and thicker (up to a few meters). The formation is known throughout the basin and is called Volče Limestone. It is of Coniacian to Campanian age (O gorelec et al., 1976, 1996, Buser, 1987). The top and northern slope of the Mt. Mrzli vrh is made of basal breccias of the Maastrichtian Upper flyschoid formation (Cousin, 1981). The described differences between northern and southern blocks imply that the bounding fault is most probably a reactivated Mesozoic fault.

The Mesozoic succession of the Mt. Mrzli vrh area is thrust over the Upper flyschoid formation that, with a strong stratigraphic gap, overlies the Upper Triassic Dachstein Limestone. Structurally, the underlying block belongs to the Trnovo Nappe of the Dinarides (Buser, 1987).

\section{Description of the Mt. Grmuč section}

The Mt. Grmuč section is located on the southern slope of Mt. Grmuč, in trenches from World War I (Fig.2). It begins on a minor ridge (altitude $900 \mathrm{~m}$ ) below the small peak of $\mathrm{Na}$ vrhu $\left(46^{\circ} 12^{\prime} 60^{\prime \prime} \mathrm{N}, 13^{\circ} 43^{\prime} 27^{\prime \prime} \mathrm{E}\right)$ and ends below the mountain saddle (altitude $980 \mathrm{~m}$ ) between the peak of $\mathrm{Na}$ vrhu and Mt. Grmuč. The section is composed of coarse-grained carbonate breccia, microbreccia, calcarenite and micritic limestone (Fig. 3B). Three thick coarse-grained breccia beds outstand in the section. Upwards, the succession is poorly exposed but carbonate gravity-flow deposits outcrop for approximately 10 meters. With a sharp contact the marly top of the Lower flyschoid formation characterized by red marl, marly limestone and a horizon of dark green marl, shale and chert impregnated with manganese is overlain.

Breccia is characterized by thick (up to $6 \mathrm{~m})$ non-graded beds and thin to medium beds that usually grade into microbreccia, coarse- to medium- rarely fine-grained calcarenite. Some graded beds in the lower part of the section are channelized (Fig. 3C). The coarse-grained breccia (clasts up to $10 \mathrm{~cm}$ ) is clast-supported, whereas the finegrained breccia and microbreccia reveal a grain-supported texture. The breccia is composed of lithoclasts and bioclasts: echinoderm fragments, bivalve and brachiopod shells (Pl. 2, Figs. 3, 4). A few cm long, fibrous, brachiopod shells are common in the upper $20 \mathrm{~m}$ of the section. They are oriented parallel to the bedding. The roundness of the lithoclasts depends mostly on their diverse composition. With regard to the depositional environment two major groups of clasts are distinguished.

Lithoclasts of shallow-water origin: (1) Grainstone lithoclasts are composed of ooids, peloids, intraclasts and fossils: echinoderm fragments, bivalve shells and foraminifers. Other grains are pellets, oncoids and grapestones (Pl. 1, Figs. 1, 2). The proportion of allochems varies significantly within grainstone lithoclasts. Common are lithoclasts with prevailing ooids that show a radial and tangential structure $(\mathrm{Pl} .1$, Fig. 1, Pl. 2, Fig. 1). Fibrous rim and drusy mosaic cements are predominant. Some grainstone lithoclasts are strongly recrystallized. (2) Lithoclasts that exhibit a fenestral structure are composed of micritic laminas with encrusted pellets and rare coarser allochems such as ooids or oncoids and laminae of sparite (Pl. 1, Fig. 3). (3) Stromatolite lithoclasts are also quite common. 


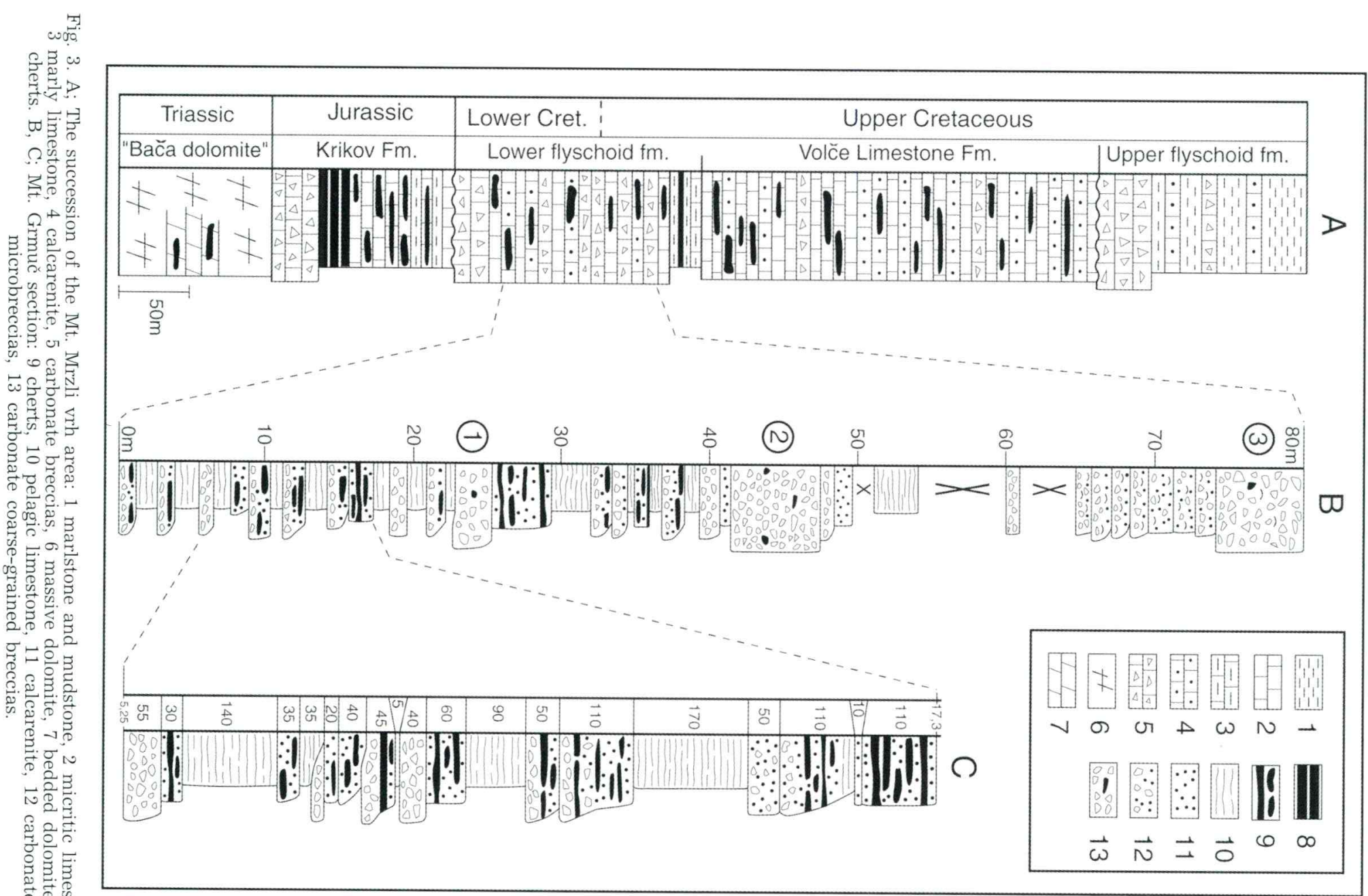


These lithoclasts are mostly rounded but some, especially oolitic grainstone clasts, are angular. Sphericity varies significantly, but elongated lithoclasts prevail.

Clasts of deep-water origin: (1) Mudstone to wackestone clasts can contain planktonic foraminifers, calcispheres and/or calcified radiolarians, sponge spicules, thin-shelled bivalves, calpionellas and unrecognizable fossil debris. The proportion of fossils varies within particular clasts. Clasts with planktonic foraminifers represent mudchips of eroded contemporaneous pelagic limestone (Pl. 1, Fig. 4), while others represent eroded lithoclasts of older pelagic successions. Among these, mudstone lithoclasts with Calpionella alpina of the Biancone limestone were recognized (Pl. 1, Figs. 5, 6). (2) Finegrained packstone and grainstone clasts are of the same structure and composition as the calcarenite microfacies described in the following paragraph. They represent eroded sand-sized members of the investigated formation. Clasts of deep-water origin are usually well rounded and elongated. Some of them show plastic deformation.

Other lithoclasts: common are packstone lithoclasts with a composition similar to the grainstone lithoclasts already described. Allochems, especially ooids, are mostly micritized. The micritic matrix is often recrystallized to microsparite. These lithoclasts are most probably of shallowwater origin. Some mudstone, wackestone and packstone clasts contain mostly echinoderm and other unrecognizable debris (Pl. 2, Fig. 1). It is impossible to determine the depositional environment of these clasts. They were at least partly formed on an adjacent platform, since one of these clasts contains a bryozoan grain encrusted by a stromatoporoid. Few lithoclasts are made of sparite without recognizable allochems (Pl. 2, Fig. 1). Occasionally they exhibit a slightly fibrous structure. Other clasts are rare. Among these, three interesting clasts are outlined: a lithoclast made of micrite and laminated structure of partly silicified radiaxial fibrous cement that fills a larger void, a lithoclast that comprises a possible hardground and a clast of limonitized oncoide with a grainstone core composed of peloids, pellets and ooids (Pl. 2, Fig. 2).

Among diagenetic features, dissolution and selective silification are present (Pl. 2,
Figs. 3, 4). Silification is observed predominantly in fibrous shells and micritic clasts. Shells are replaced by microcrystalline quartz. In the micritic clasts both microcrystalline and up to $100 \mu \mathrm{m}$ long euhedral to subhedral quartz crystals are present. Be-

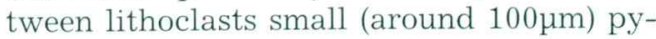
rite anhedral to subhedral crystals occur $(\mathrm{Pl}$. 2, Fig. 1). Strong dissolution is observed in coarse breccias, where contacts between clasts are stylolitic (Pl. 2, Fig. 1). In microbreccias dissolution is scarce and only occurs in larger clasts. Cement is predominantly blocky sparite. Syntaxial cement is observed around echinoderm fragments.

Calcarenite forms isolated beds ( 0.1 to $4 \mathrm{~m}$ thick) or composes upper parts of graded breccia beds. Texture is coarse to fine grainstone and very fine packstone. Normal grading and parallel lamination are apparent. Thin sections revealed that ripple cross and upper parallel lamination of the Bouma sequence is also present. The $\mathrm{T}_{\mathrm{e}}$ Bouma division is possibly incorporated in overlying micritic limestone packages. In normally graded parts an imbrication of shells and other elongated debris is usual. Orientation is parallel to the bedding. The composition of coarse grainstone is very heterogeneous, but becomes monotonous with decrease in grain size. Grains are fossils, peloids, micritic intraclasts, micritized ooids and rare oncoids. Since the transition from microbreccias is gradual, in the coarser grainstone lithoclasts are still present (Pl. 2, Fig. 5, Pl. 3, Fig. 2). Fossils are bivalve and brachiopod shells, foraminifers and other fossil debris. Two types of bivalve shells are common: shells made of prismatic calcite perpendicular to the shell wall belonging to Inoceramus ( $\mathrm{Pl} .1$, Fig. 5) and shells with fibrous, foliated walls and cores made of fibrous cross-laminated calcite (Pl. 2, Fig. 4). Among benthic foraminifers biostratigraphically important is Orbitolina (Pl. 2, Fig. 5, Pl. 3, Fig. 1). Other benthic foraminifers are Textularia, Lenticulina and Miliolidae (Pl. 3, Fig. 3). Echinoderm plates have micritized rims and compose up to $50 \%$ of grains in the finer grainstone. Other fossil debris is rare. In the upper part of the section glauconitic grains are present. The content of fine grainstone and very fine packstone is reduced to micritic intraclasts and/or pellets, planktonic foraminifers and 
fossil debris, mostly echinoderms. Foraminifers belong to globotruncanids and some exhibit keeled chambers (Pl. 3, Fig. 2, 4). Clay is present and is concentrated in thin laminae (Pl. 3, Fig. 4).

Grainstone contains chert nodules. In unreplaced grainstone a selective silification of fibrous shells and sometimes micritic intraclasts occurs. The fine grainstone and very fine packstone contain small (around $100 \mu \mathrm{m})$ pyrite anhedral to subhedral crystals (Pl. 2, Fig. 5, Pl. 3, Fig. 4). Sometimes they exhibit radial growth from a crystal core. Dissolution is scarce and reserved for larger grains and bedding planes. In grainstone cement is blocky sparite and around the echinoderm debris there is syntaxial cement. The micritic matrix in very fine packstone is occasionally recrystallized to microsparite.

Micritic limestone (wackestone/mudstone) occurs in up to $3 \mathrm{~m}$ thick packages that exhibit indistinctive bedding. It is dark grey, sometimes marly and exhibits unclear wavy and parallel lamination. Grains are fossils: planktonic foraminifers, calcispheres and/or calcified radiolarians, sponge spicules, thin-shelled bivalves, ostracodes and other tiny fossil debris (Pl. 3, Fig. 5).

Among diagenetic features dissolution is present. Stylolites, oriented parallel to the bedding, are common. Replacement by small (up to $50 \mu \mathrm{m}$ ) spherical pyrite crystals is common. Framboidal pyrite is concentrated in up to a few $\mathrm{cm}$ wide ellipsoid tubes that are continuous through beds and oriented parallel to the bedding planes (Pl. 3, Fig. 6). Presumably, these structures are related to bioturbation. They can be macroscopically observed as light brown limonitized spots.

\section{Depositional environment}

The composition of the resedimented carbonates reveals that sand-sized material is composed mostly of peloids, micritic intraclasts, micritized ooids, bivalve and brachiopod shells, foraminifers, echinoderm fragments and other fossil debris. These grains were transported from the Dinaric Carbonate Platform and cemented in a deepwater environment. Breccias are composed of diverse platform and basin lithoclasts and slope/basin intraclasts. Lithoclasts of older platform carbonates, predominantly bindstone and oolitic grainstone, are common. The Jurassic age of some platform lithoclasts was proven by green algae and benthic foraminifers (Buser, 1987) but older, i.e. Triassic platform limestone clasts are also assumed to be present (Buser, 1987, Samiee, 1999). Lithoclasts of pelagic Biancone limestone were recognized. This implies the exposure and erosion of the older platform and basin carbonates and also the erosion of the contemporaneous slope and basin sediments.

Sedimentary structures $\left(\mathrm{T}_{\mathrm{a}}-\mathrm{T}_{\mathrm{d}}\right.$ Bouma divisions) in coarse-grained beds indicate that most of the resedimented material was deposited by turbidity flows. A complete Bouma sequence is rarely preserved and topcut-off sequences prevail. Three breccia megabeds that outstand in the Mt. Grmuč section show no internal organization and debris flow or high density turbidity flow transport is proposed as the origin of these beds. At least the upper two, thicker breccia beds are continuous through the northern block in the Mt. Mrzli vrh area and represent debris flow sheets.

Gravity-flow deposits are interbedded within packages of micritic limestone. The composition of this limestone indicates sedimentation in a pelagic environment. It is assumed that the carbonate mud is allochtonous since in the central part of the basin lime-poor to lime-free shally sediments prevail (Buser, 1996; Cousin, 1981). Two interpretations are proposed here to explain the occurrence of micritic limestone only in the proximal area. (1) Lime mud was continuously dispersed from the adjacent Dinaric Carbonate Platform to the basin. Therefore, the wackestone/mudstone microfacies represent hemipelagic sedimentation. (2) Lime mud was deposited by gravity-flows. It was sedimented by low-density turbidity-flows or represents the muddy part of the calcareous turbidites that was redispersed into the water column and resettled slowly as background sediment (E berli, 1991). The lack of distinctive bedding as well as the parallel and wavy laminations that occasionally occur in micritic limestone would favor a gravity-flow-related interpretation. The continuous presence and geometry of common framboidal pyrite con- 
centrations indicate that hemipelagic lime mud was permanently subjected to bioturbation.

The described facies association of the Mt. Grmuč section, where pelagic limestone is interbedded with debrites and top-cut-off turbidites, indicates a lower slope depositional setting (Emery \& Myers, 1996). In the apron model (usually recommended for resedimented carbonates) the Grmuč section corresponds to the facies association of the outer apron facies (Facies A in Mullins \& Cook; 1986; Emery \& Myers, 1996). The fact that breccia beds are channelized only in the lower part of the section and in the upper part debris flow sheets occur may suggest a change to a more distal depositional environment over time.

The investigated succession is abruptly overlain by marl to shale, interbedded with marly limestone and chert. This change in sedimentation is probably a consequence of the late Cenomanian regional transgression (Haq et al., 1988) also recorded on the Dinaric Carbonate Platform (Jurkovšek et al., 1996). The manganese impregnated horizon that occurs in this part may correspond to the OAE2 - Bonarelli level that coincides with maximum transgression at the Cenomanian-Turonian boundary (Schlanger \& Jenkyns, 1976; Premoli Silva et al., 1999; Pancost et al., 2004).

\section{Correlation with the central part of the Slovenian Basin and the Dinaric Carbonate Platform}

In the central part of the Slovenian Basin the Jurassic and lowermost Cretaceous succession is entirely preserved (Cous in, 1973; Buser, 1987; Rožič, 2005). The Biancone limestone is overlain with erosional contact by the Lower flyschoid formation composed of shale, marl and chert interbedded with distal carbonate turbidites. Locally, the formation begins with basal breccia that is a few meters thick. Buser $(1987,1996)$ proposed a stratigraphic gap between the Berriasian and Aptian. In Caron \& Cousin (1972), the Albian to Turonian is proven for the Lower flyschoid formation and the base is only presumably assigned to the Aptian due to the absence of characteristic fossils in the basal part of the forma- tion. Abundant resedimented carbonates occur in the Lower flyschoid formation only in the Mt. Mrzli vrh and Tolminske Ravne areas (Buser, 1987; Samiee, 1999). The Tolminske Ravne succession studied by Samiee (1999) belongs to the structurally higher Rut Nappe where more distal basinal facies are exposed. In this area the Lower flyschoid formation overlies the Berriasian Biancone limestone that is laterally eroded and basal breccia lies directly on Upper Jurassic radiolarian cherts. The horizon of basal breccia is up to $30 \mathrm{~m}$ thick and consists of a few large gravity-flow events. From fossils found in resedimented material Samiee (1999) assumed an early Valanginian - late Aptian age for the basal breccia. The breccia is composed of reef limestone and various lithoclasts of much older platform and basinal successions (Buser, 1987; Samiee, 1999). Since they were most likely deposited during a relatively short time interval, it is probable that their age is late Aptian or early Albian. By Cousin (1973), who focused on Jurassic succession of this area, this horizon is included in the study and is assigned to the Albian. Basal breccia is overlain by $50 \mathrm{~m}$ of basin plain deposits, characterized by shale, chert and fine-grained carbonate turbidites. Upwards, this middle part of the formation gradually passes into upper Albian to lower Cenomanian resedimented carbonates (Samiee, 1999) which are correlatable to the studied succession of the Mt. Mrzli vrh area, but exhibit more distal turbidite facies associations. The occurrence of abundant resedimented carbonates in the Tolmin region, i.e. in the western part of the Slovenian Basin and their decline towards the east, indicate that the strongest redeposition of the carbonate material was originally limited to the western part of the basin. On the other hand, the distribution of facies can also be explained by the complex geological structure of western Slovenia. As a consequence of the Dinaric thrusting facies belts would extend from the Tolmin region to the southeast. But the subsequent Southalpine thrusting resulted in the present-day situation of the southern boundary of the Slovenian Basin extending in a west-east direction and consequently no basinal succession is preserved in the area southeast of Tolmin. 
The composition of the resedimented carbonates reflects the production and erosion of the adjacent platform. From platformderived material, orbitolinas are most convenient for the correlation with platform successions. Limestone with orbitolinas is reported from the Dinaric Carbonate Platform (Pleničar, 1970; B us er, 1973, 1987; Šribar, 1979). Recent work by Dozet \& Šribar (1998) in south-eastern Slovenia reveals that orbitolinas are present through the Aptian and Albian, but are rock-forming in upper Orbitolina limestone of the Albian age. A similar trend is observed in the Aptian to lower Cenomanian Povir Formation in the Karst region (Jurkovšek et al., 1996). Increased Orbitolina abundance is reported above the Aptian-Albian boundary represented by an emersion surface. This emersion is observed throughout the Dinaric Carbonate Platform (B enček et al., 2003; Velić et al., 2003; Vlahović et al., 2003,) and coincides with the demise of the Aptian reef that rimmed the northern margin of the platform (Turnšek \& Buser, 1974, Koch et al., 1989, Turnšek, 1997). According to Sartorio et al. (1997), another important breccia horizon is present within the marginal setting of the Dinaric Carbonate Platform in the middle Albian. Below this horizon restricted carbonate platform facies predominate, while above this horizon only open platform facies occurs (Fig. 4). They interpret this change of sedimentation with intense subsidence of the platform margin.

The correlation of the studied succession with other basinal and platform successions (Fig. 4) elucidates possible factors control-

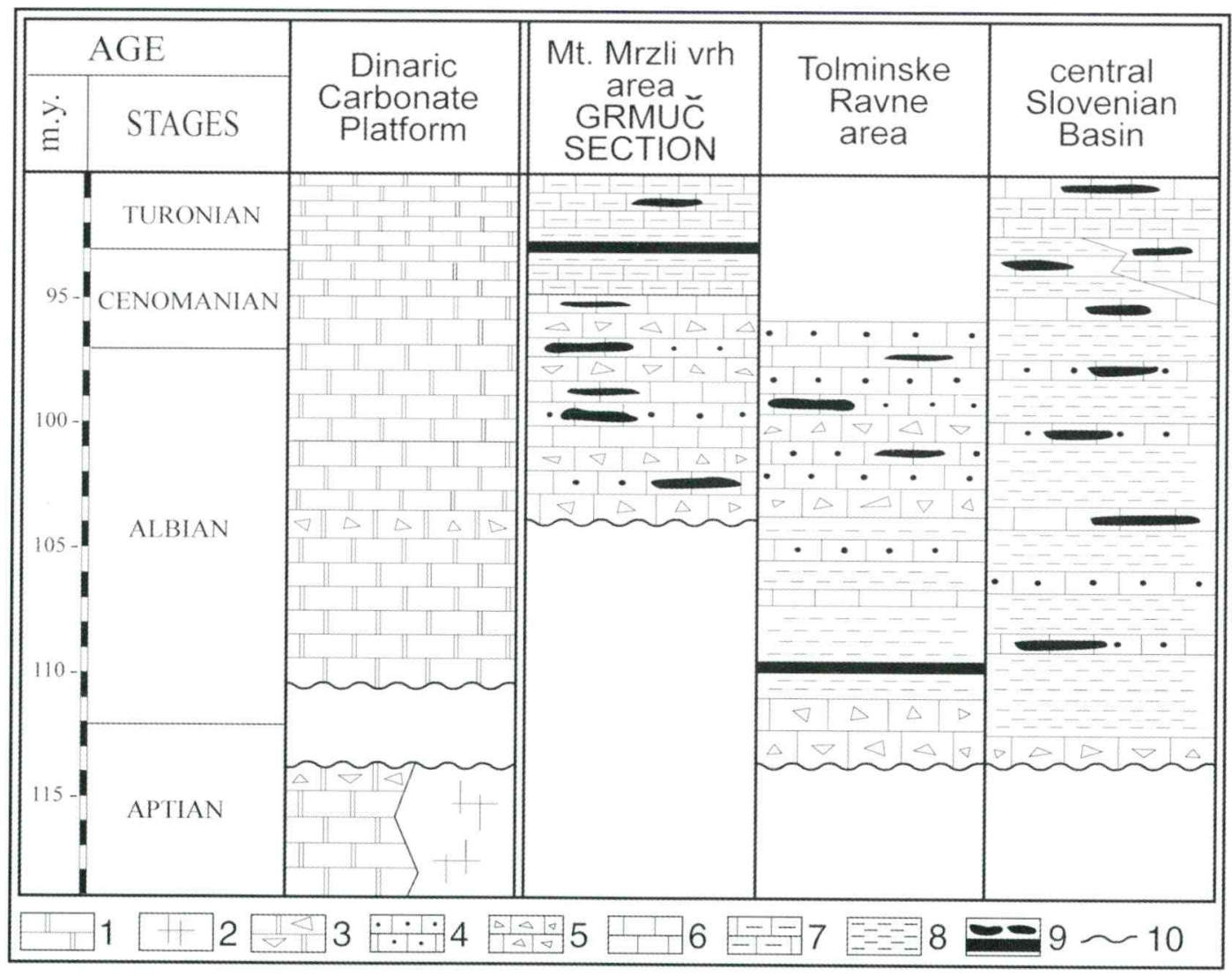

Fig. 4. Correlation with the successions of the Dinaric Carbonate Platform (compiled after Buser, 1987, Jurkovšek et al., 1996 \& Sartorio et al., 1997), the Tolminske Ravne area (after

Samiee, 1999) and the central part of the Slovenian Basin (compiled after Caron \& Cousin, 1972, Cousin, 1981 \& Buser, 1987): 1 platform carbonates, 2 reef limestone, 3 platform breccia, 4 calcarenite, 5 breccia, 6 micritic limestone, 7 marly limestone, 8 shale and marl, 9 cherts, 1 erosion. 
ling the deposition of Albian and Cenomanian in the Slovenian Basin. Here it is interpreted that the basal breccia of the Lower flyschoid formation originated during a relative sea-level low stand (cf. Spence \& Tucker, 1997) and are correlatable with the Aptian - Albian emersion on the platform. The abundance of platform lithoclasts much older than Albian indicates that the sedimentation of basal breccia was primarily controlled by tectonics. The onset of resedimentation in the Mt. Mrzli vrh area was delayed. It occurred simultaneously with the sedimentation of the upper part of the formation in the Tolminske Ravne area and with middle Albian subsidence on the platform margin. Resedimentation lasted up until late Cenomanian when the Dinaric Carbonate Platform was entirely flooded (Cucchi et al., 1989; Jurkovšek et al., 1996; Fuček et al., 2003; Velić et al., 2003; Vlahović et al., 2003). Resedimentation ceased as a consequence of the platform flooding.

\section{Reconstruction of the paleotopography}

No continuous platform to basin sedimentary record is preserved between the Dinaric Carbonate Platform and the Slovenian $\mathrm{Ba}-$ $\sin$. But the composition of the breccias and the geological mapping of the Mt. Mrzli vrh area contribute to reconstruction of the upper Albian to lower Cenomanian topography between these two paleogeographic units.

Geological mapping of the Mt. Mrzli vrh area reveals that the area is divided by an $\mathrm{E}-$ $\mathrm{W}$ trending fault in blocks with distinctively different successions. In the southern block that was more proximal to the Dinaric Carbonate Platform the Lower flyschoid formation is thicker and lies directly on Triassic massive dolomite. In the northern block the Lower flyschoid formation is thinner and overlies an incomplete Jurassic succession. Further to the north, in the central part of the Slovenian Basin much more continuous Jurassic and Cretaceous succession is preserved (Buser 1987, 1996). This difference is interpreted here as a consequence of synsedimentary normal faulting, where northern blocks were more subsided and less erosion of older strata was present (Fig 5a).
In addition, the thickness of Jurassic succession in southern blocks, i.e. in a marginal basinal setting, was probably reduced and consequently this underlying succession was more easily removed. As described in the previous chapter, increased Albian tectonic activity is reported as well from the northern margin of the Dinaric Carbonate Platform. Contemporaneous fragmentation and intense subsidence of separated blocks is also reported from Istria (Croatia) that belonged to the northern part of the same platform (Adriatic-Dinaric Carbonate Platform in: Fuček et al., 2003; Velić et al., 2003; Vlahović et al., 2003). Therefore, we can conclude that the tectonic activity intensified in the middle Albian which led to normal faulting and the subsidence of entire region. It is believed here that tectonics is the main mechanism controlling the upper Albian to lower Cenomanian sedimentation also recorded in the studied succession.

The composition of resedimented carbonates proves the erosion of older platform carbonates and slope-to-basin strata. If minor, short-lasting emersion horizons are neglected, continuous Triassic to Cretaceous succession is preserved on the Dinaric Carbonate Platform (Buser, 1996). Considering these facts, the erosion is limited to the slope area. Therefore, a steep slope with fault-related escarpments, where erosion of the older platform, slope and basin strata occurred, is proposed to explain the described sedimentary conditions (Fig. 5b).

\section{Conclusions}

The upper Albian to lower Cenomanian carbonate succession of the Mt. Mrzli vrh area is characteristic of a lower slope depositional environment. In the Mt. Grmuč section micritic limestone is interbedded with resedimented carbonates, mostly turbidites. The structureless megabeds of clast-supported breccias are interpreted as debrisflow deposits. The resedimented carbonates are composed of coeval platform and slopeto-basin isolated grains, slope-to-basin intraclasts and lithoclasts of older deposits. Platform-derived material mainly involves peloids, intraclasts, rare ooids and fossils: brachiopod and bivalve shells, echinoderms debris and foraminifers of which orbitolinas 


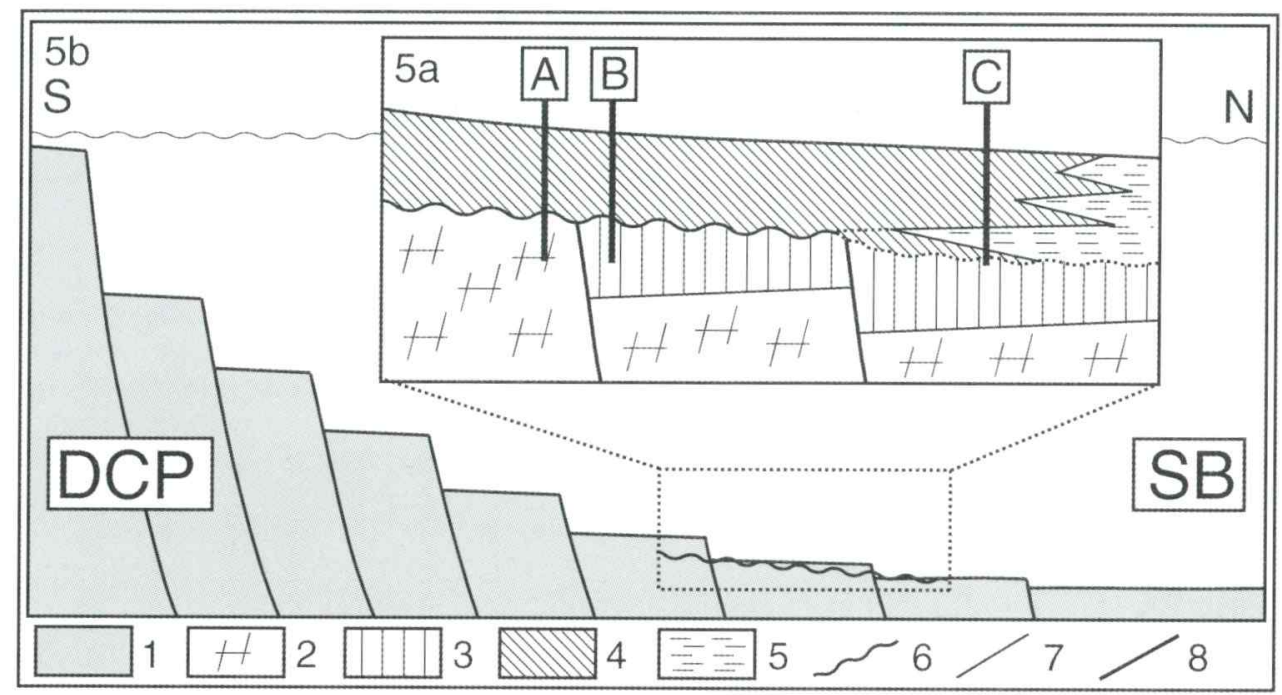

Fig. 5. Schematic cross-section in the Albian-Cenomanian (not to scale): 1 faulted slope, 2 Triassic basement, 3 Jurassic basinal succession, 4 Resedimented carbonates, 5 shale, marl, 6 erosional boundary, 7 normal boundary, 8 fault, DCP Dinaric Carbonate Platform, SB Slovenian Basin, A Southern block of the investigated area, B northern block of the investigated area, C Tolminske Ravne area.

are the most abundant. Lithoclasts are diverse and exhibit various platform and slope-to-basin sedimentary environments. Middle Jurassic oolitic limestone and Upper Jurassic to Lower Cretaceous Biancone limestone were proven with microfossils. This implies the erosion of much older platform and basinal successions. Beside the composition, the erosion of the underlying basinal succession is evident from a long stratigraphic gap below the Lower flyschoid formation. The Mt. Mrzli vrh area is divided into two blocks by a strong E-W extending fault. Although not entirely preserved, the Jurassic succession is still present in the northern block whereas in the southern block the Lower flyschoid formation lies directly on Upper Triassic massive dolomite.

The correlation with coeval successions in the central part of the Slovenian Basin and the adjacent Dinaric Carbonate Platform indicates the main controlling factors and events in the sedimentation of the Albian and Cenomanian in the discussed area. The facies association of the Mt. Mrzli vrh area, that represents a proximal variety of the Lower flyschoid formation, is present only in the westernmost part of the Slovenian Basin. This is interpreted as a consequence of major gravity-flow input in the western part of the basin. But it could also be an artifact due to the complex geological struc-

\section{Plate 1}

1 Grainstone lithoclast composed of ooids and aggregate grain cemented by rim and drusy mosaic cements within the clast (a), but cemented by blocky cement with other lithoclasts (b - in the lower part of the photograph).

2 Grainstone lithoclast composed of ooids, pellets, peloids and aggregate grains.

3 Lithoclast with fenestral porosity.

4 Wackestone intraclast with globotruncanids, other fossil debris, framboidal pyrite and stylolitized contact with other clasts.

$5 \quad$ Inoceramus shell and mudstone lithoclast with calpionellids.

6 Enlargement of Fig.5; mudstone with Calpionella alpine. 

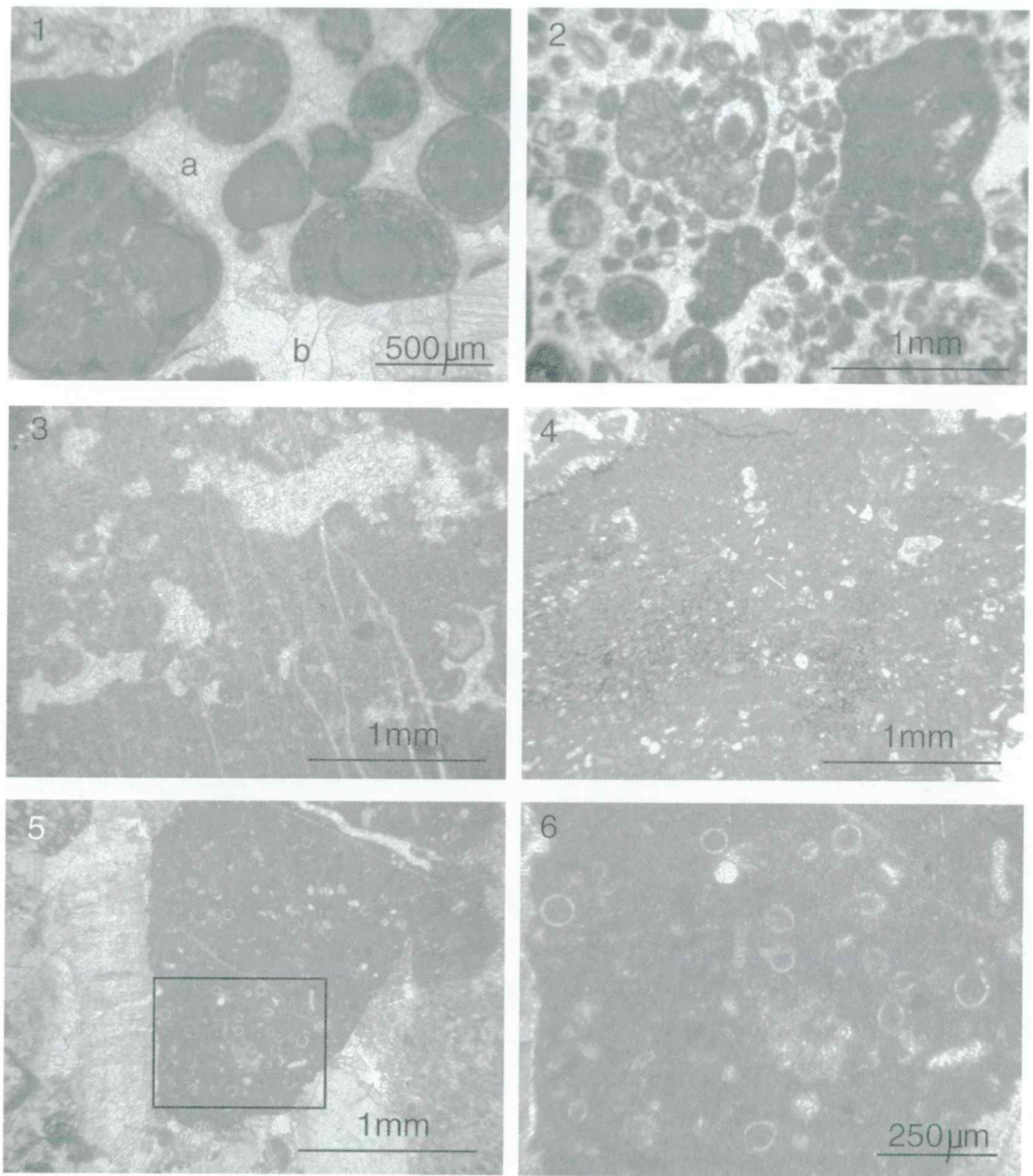
ture of western Slovenia. The base of the Lower flyschoid formation in the central basin is older and usually characterized by basal breccia. This breccia correlates with the late Aptian to early Albian emersion of the Dinaric Carbonate Platform. But the onset of the carbonate resedimentation in upper Albian recorded in the Mt. Mrzli vrh and Tolminske Ravne areas coincides with middle Albian subsidence on the platform margin. Regionally evidenced intense tectonic activity is also reflected in the geological setting of the Mt. Mrzli vrh area and is probably the main mechanism controlling the resedimentation in the studied succession. The decrease of gravity-flow deposits in the Mt. Mrzli vrh area correlates with late Cenomanian flooding of the Dinaric Carbonate Platform.

The study of the Lower flyschoid formation in the Mt. Mrzli vrh area is also important for the Albian and Cenomanian paleotopographic reconstruction because this area represents the link between the central Slovenian Basin and the Dinaric Carbonate Platform. The composition of lithoclast in the resedimented carbonates of the Lower flyschoid formation, the observed lateral facies distribution and the increasing stratigraphic gap below the formation in the direction of the Dinaric Carbonate Platform indicate a steep, fault-bounded slope.

\section{Acknowledgments}

The detailed geological map of the Mt. Mrzli vrh area was made with the help of students from the Department of Geology, University of Ljubljana. Mapping was carefully supervised by Stanko Buser and Uroš Herlec. A significant contribution to understanding the complex structure of the mapped area was made by Jože Čar. Special thanks go to Tomislav Popit for his help with field-work. Špela Goričan is gratefully acknowledged for her helpful consultations and for reviewing the manuscript. Murray Bales is thanked for useful English correction of the final text.

\section{References}

B enček, Đ., Fuček, L., Matičec, D., Oštrić, N. \& Vlahović, I. 2003: Regionally Important Lower Cretaceous Lithofacies Units in the Biokovo Mt.- in: Vlahović, I. \& Tišljar, J. (eds.): Field Trip Guidebook, $22^{\text {nd }}$ IAS Meeting of Sedimentology - Opatija 2003, 83-92, Zagreb.

Buser S. 1973: Tolmač lista Gorica, Osnovna geološka karta SFRJ 1: 100 000. - Zvezni geološki zavod, 74pp., Beograd.

B us er, S. 1986: Osnovna geološka karta SFRJ 1: 100 000, list Tolmin. - Zvezni geološki zavod, Beograd.

Bus er, S. 1987: Tolmač listov Tolmin in Videm (Udine), Osnovna geološka karta SFRJ 1: 100000. - Zvezni geološki zavod, 103 str., Beograd.

Buser, S. 1989: Development of the Dinaric and Julian carbonate platforms and the intermediate Slovenian basin (NW-Yugoslavia). - in: Carulli, G.B., Cucchi, F. \& Radrizzani, C.P. (eds.): Evolution of the Karstic carbonate platform: relation with other periadriatic carbonate platforms. - Mem. Soc. Geol. Ital., 40, (1987), 313-320, Roma.

Buser, S. 1996: Geology of western Slovenia and its paleogeographic evolution. - in: Drobne, K., Goričan, S. \& Kotnik, B. (eds.): The role of Impact Processes in the Geological and Biological Evolution of Planet Earth. International workshop, ZRC SAZU, 111-123, Ljubljana.

Caron, M. \& Cousin, M. 1972: Le sillon slovène: les formations terrigènes crétacées des unites externes au Nord-Est de Tolmin (Slovénie occidentale). - Bull. Soc. Géol. France, 14, 34-45, Paris.

\section{Plate 2}

1 Anhedral pyrite and stylolitic contacts between: (a) sparite clasts, (b) an ooidal grainstone lithoclast and (c) a wackestone to packstone lithoclast with no recognizable fossil debris.

2 Limonitized oncoide with grainstone core and algal encrustment.

3 Diagenetic features; selective silification of the fibrous shell (a silicified part, b unreplaced part) and dissolution on contact with ooidal grainstone lithoclast.

Diagenetic features; dissolution of shell with fibrous, foliated walls and a core made of fibrous cross-laminated calcite.

5 Grainstone with subhedral pyrite crystals and micritic intraclasts/peloids and lithoclast with Calpionella sp.

6 Grainstone with orbitolinas, peloids, echinoderm fragments, micritic intraclast and a clast of recrystallized mudstone. 

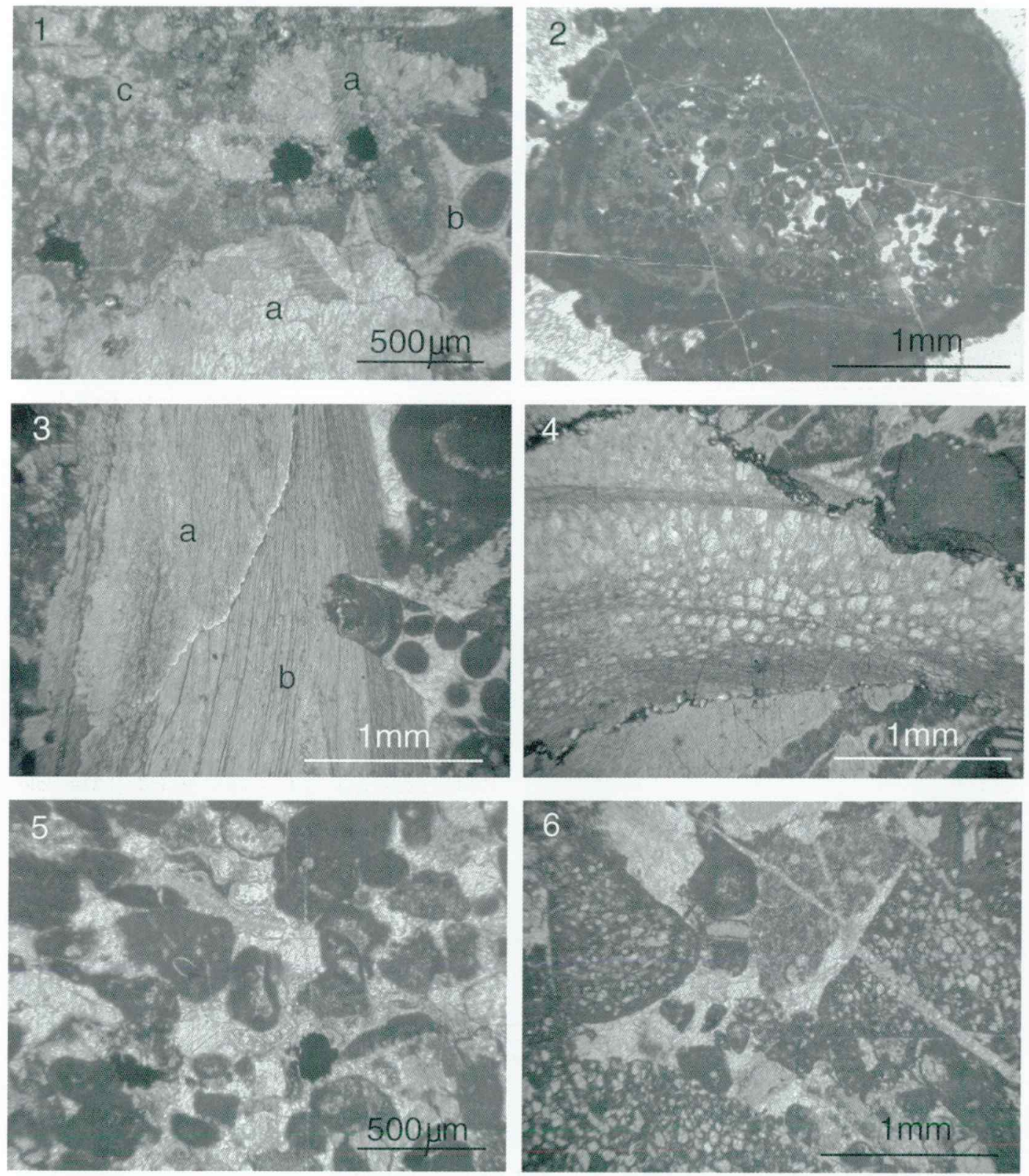
Caron, M. 1985:Cretaceous planktonic foraminifera.- in: Bolli, H.M., Sa unders, J.B. \& Perch-Nielsen (eds.): Plankton Stratigraphy, 17 - 86, Cambridge University Press, Cambridge

Cous in, M. 1973: Le sillon slovene: les formations triasiques, jurassiques et neocomiennes au Nord - Est de Tolmin (Slovenie occ., Alpes mer.) et leurs affinites dinariques, Bull. Soc. Géol. France, $7 / X V, 326$ - 339, Paris.

Cousin, M. 1981: Les repports Alpes Dinarides Les confins de I'talie et de la Yougoslavie:-Publication $n^{\circ} 5$, vol II, 1 -521, Societe geologique du nord, Villeneuve.

Cucchi, F., Pirini Radrizzani, C. \& Pugliese, N. 1989: The carbonate stratigraphic sequence of the Karst of Trieste (Italy). - Mem. Soc. Geol. Ital. 40 (1987), 35-44, Roma.

Dognioli, C. \& Bosellini, A. 1987: Eoalpine and mesoalpine tectonics in the Southern Alps. - Geol. Rundsch., 76, 735-754, Stuttgart.

Dognioli, C. \& Siorpeas, C. 1990: Polyphase deformations in the $\mathrm{Col}$ Bechei area (Dolomites-Northern Italy). - Eclogae geol. Helv., 83, 701-710, Basel.

Dozet, S. \& Sribar, L. 1998: Lower Cretaceous Shallow-Marine Sedimentation and Biota on Dinaric Carbonate Platform between Logatec, Krka and Kolpa (Southeastern Slovenia). Geologija 40 (1997), 153-186, Ljubljana.

Eberli, G.P. 1991: Calcareous Turbidites and Their Relationship to Sea-Level Fluctuations and Tectonism. - in: Einsele, V., Ricken, G. \& Seilacher, A. (eds.): Cycles and Events in Stratigraphy, 340 - 359, Springer - Verlag, Berlin.

Emery, D. \& Myers, K.J.1996: Carbonate system:-Sequence Stratigraphy, 211-237, 297pp., Blackwell Science, Oxford.

Fuček, L., Vlahović, I., Tišljar, J., Velić, I., Husinec, A., Korbar, T., Matičec, D., Oštrić, N., Prtoljan, B., Palenik, D. \& Ibrahimpašić, H. 2003: Dynamics of latest Albian-Cenomanian sedimentary environments in the NW part of the Adriatic Carbonate Platform (Istria and northern Adriatic Islands, Croatia). in: Vlahović, I. (ed.): Abstracts book, $22^{\text {nd }}$ IAS Meeting of Sedimentology - Opatija 2003, 60, Zagreb.

Haq, B.U., Hardenbol, J. \& Vail, P.R. 1988: Mesozoic and Cenozoic Chronostratigraphy and Cycles of Sea Level Changes. - in: Wilgus C.K., Hastings, B.S. Ross, C.A., Posamentier, H., van Wagoner, J \& Kendal, C.G.C. (eds.), Sea Level Changes: An
Intergraded Approach, SEPM Spec. Publ. 42, 71108, Tulsa.

Jurkovšek, B., Toman, M., Ogorelec, B., Šribar, L., Drobne, K., Poljak, M. \& Šribar, L. 1996:

Formacijska geološka karta Južnega dela Tržaško-Komenske planote; kredne in paleogenske kamnine, 1:50 000.-Tolmač, 143pp. Geološki zavod Ljubljana, Ljubljana.

Koch, R., Ogorelec, B. \& Orehek, S. 1989: Microfacies and diagenesis of Lower and Middle Cretaceous carbonate rocks of NW-Yugoslavia (Slovenia, Trnovo area). - Facies, 21, 135-170, Erlangen.

Kossmat, F. 1907: Geologie des Wocheiner tunnels und der sudlichen anschlusslinie. Denkschriften d. mathem. - naturwis. K1. Bd. 83, 41-142, Wien.

Leonidakis, J., Herlec, U \& Buser, S. 2003: Novi rezultati podrobnega kartiranja med vasjo Gabrje in Mrzlim vrhom pri Tolminu. Geološki zbornik - povzetki referatov, 17, 109110, Ljubljana.

Mullins, H.T. \& Cook, H.E. 1986: Carbonate Apron Models: Alternatives to the Submarine Fan Model for Paleoenvironmental Analysis and Hydrocarbon Exploration. - Sedimentary Geology, 48, 37-79, Amsterdam.

Ogorelec, B., Sribar, L. \& Buser, S. 1976 : On lithology and biostratigraphy of Volče Limestone. - Geologija, 19, 125-151, Ljubljana.

Ogorelec, B., Buser, S. \& Sribar, L. 1996 Doblar in the Soča Valley, the Volče Limestone (Campanian Allodapic Limestone). - in: D robne, K., Goričan, S. \& Kotnik, B. (eds.): The role of Impact Processes in the Geological and Biological Evolution of Planet Earth. International workshop, ZRC SAZU, 211-213, Ljubljana.

Pancost, R.D., Crawford, N., Magness, S., Turner, A., Jenkyns, H.J. \& Maxwell, J.R. 2004: Further evidence for the development of photic-zone euxinic conditions during Mesozoic oceanic anoxic events. - Journal of the Geol. Soc., 161, 353-364, London.

Placer, L. \& C a r, J. 1998: Structure of Mt. Blegoš between the Inner and Outer Dinarides. Geologija, 40, 305-323, Ljubljana.

Placer, L. 1999: Contribution to the macrotectonic subdivision of the border region between Southern Alps and External Dinarides, Prispevek $\mathrm{k}$ makrotektonski rajonizaciji mejnega ozemlja med Južnimi Alpami in Zunanjimi Dinaridi. Geologija 41 (1998), 223 - 255, Ljubljana.

\section{Plate 3}

Orbitolina sp. $(22,30 \mathrm{~m})$.

2 Grainstone with Rotalipora sp., bentic foraminifera, mudstone clast, recrystallized packstone lithoclasts, peloids, echinoderm fragments and sparite grain with a micritized wall.

3 Fine grainstone/packstone with Miliolidae, micritic intraclasts/peloids and abundant echinoderm fragments.

4 Very fine grainstone/packstone with abundant planktonic formaminefers, small echinoderm fragments, peloids and lamina with clay fragments and pyrite crystals.

5 Wackestone with planktonic foraminifers, ostracodes, calcispheres and/or calcified radiolarians and fossil debris. Wackestone with fossil debris and an intense concentration of framboidal pyrite. 

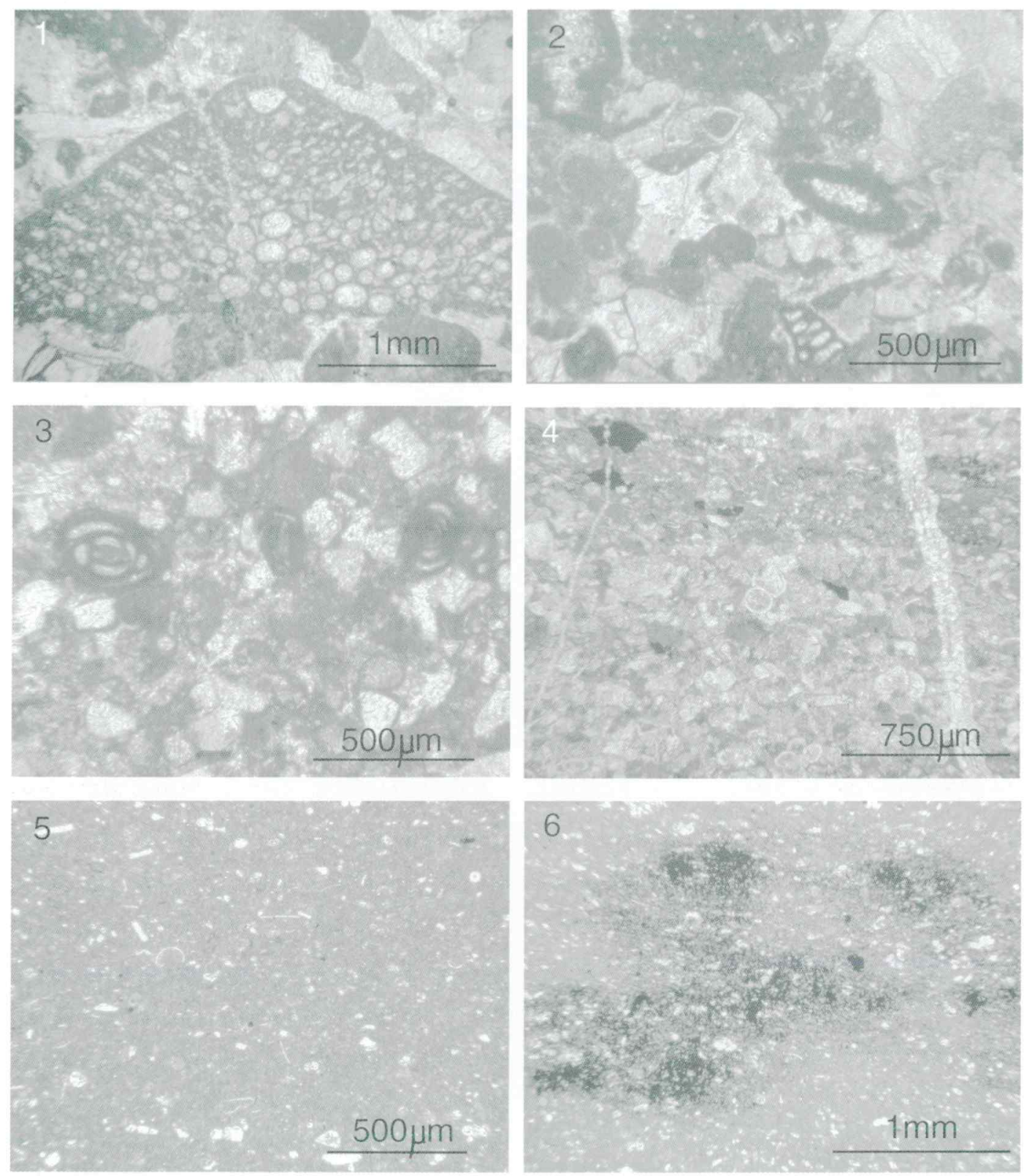
Pleničar, M. 1970: Tolmač lista Postojna, Osnovna geološka karta SFRJ 1: 100 000. - Zvezni geološki zavod, 58 str., Beograd

Premoli Silva, I., Erba, E., Salvini, G., Locatelli, C. \& Verga, D.1999: Biotic changes in Cretaceous oceanic anoxic events of the Tethys. - Journal of Foraminiferal Research, 29/4, 352370 .

Rožič, B. 2005: Stratigrafski razvoj jure v zahodnem delu Slovenskega bazena. - Geološki zbornik, povzetki referatov, 18, 107-111, Ljubljana.

Samiee, R. 1999: Fazielle und diagenetische Entwicklung von Plattform-Becken-Übergängen in der Unterkreide Sloweniens. - PhD Thesis, University of Erlangen, 185pp.

Sartorio, D., Tunis, G. \& Venturini, S. 1997: Cretaceous evolution of the Northeastern margin of the Friuli Platform (NE Italy). Mineralia Slovaca, 29, 281-283.

Spence, G.H. \& Tucker, M.E. 1997: Genesis of limestone megabreccias and their significance in carbonate sequence stratigraphic models: a review. - Sedimentary Geology, 112, 163 - 193, Amsterdam.

Schlanger, S.O. \& Jenkyns, H.C.1976: Cretaceous oceanic anoxic events: causes and consequences. - Geologie en Mijnbouw, 55, 179-184.
Šribar, L. 1979: Biostratigrafija spodnjekrednih plasti na Logaški planoti. - Geologija, 22, 277308, Ljubljana.

Turnšek, D. \& Buser, S. 1974: Spodnjekredne korale, hidrozoji, in hetetide $\mathrm{z}$ Banjške planote in Trnovskega gozda. - Razprave IV. razr. SAZU 17/2, 83-124, Ljubljana.

Turnšek, D. 1997: Mezosoic Corals of Slovenia. - Založba ZRC, 512pp., Ljubljana.

Velić, I., Tišljar, J., Vlahović, I., Matičec, D. \& Bergant, S. 2003: Evolution of the Istrian Part of the Adriatic Carbonate Platform from the Middle Jurassic to the Santonian and Formation of the Flysch Basin During the Eocene: Main Events and Regional Comparison. - in: Vlahović, I. \& Tišljar, J. (eds.): Field Trip Guidebook, $22^{\text {nd }}$ IAS Meeting of Sedimentology Opatija 2003, 3-18, Zagreb.

Vlahović, I., Tišljar, J., Velić, I., Matičec, D., Skelton, P.W., Korbar, T. \& Fuček, L. 2003: Main Events Recorded in the Sedimentary Succession of the Adriatic Carbonate Platform from the Oxfordian to the Upper Santonian in Istria (Croatia). - in: Vlahović, I. \& Tišljar, J. (eds.): Field Trip Guidebook, $22^{\text {nd }}$ IAS Meeting of Sedimentology - Opatija 2003, 19-56, Zagreb. W inkler, A. 1921: Das mittlere Isonzogebiet.Jb. Geol. B.A., 11-225, Wien. 